\title{
Model Kepemimpinan Ideal Pada Fak Tarbiyah dan Keguruan : Studi Kasus di IAIN Sultan Amai Gorontalo
}

\author{
Herson Anwar dan Lian G. Otaya \\ Institut Agama Islam Negeri Sultan Amai Gorontalo \\ herson.anwar@gmail.com,lian.otaya@yahoo.com
}

\begin{abstract}
This article is aimed to analyse the servant leadership model in achieving and reaching the vision and mission of the Faculty of Tarbiyah and Teaching Training because this model becomes an important issue applied by the education leaders. The research methodology used in this research is quantitative research with mixed method approach by Creswell. The primary data are collected though by questionnaire and secondary data by interview and documentation. The sample consists of 36 respondents by using purposive sampling technique. The result shows that from ten characteristics of servant leadership model, there are seven models implemented well. Those seven models are listening, achieving other people and emphatic, awareness, building persuasive power, service-ability, commitment, and building community. There are three models need to be improved, those are predicting ability, conceptualization, and healing ability. This leadership model is not an instant solution to solve the problem faced by the leader, but it is a long-term way, which the result comprehensively gives the change of vision and mission achievement.
\end{abstract}

\begin{abstract}
Abstrak
Artikel ini bertujuan menganalisis model kepemimpinan yang melayani dalam pencapaian visi dan misi Fakultas Ilmu Tarbiyah dan Keguruan, mengingat model ini menjadi isu penting diterapkan para pemimpin pendidikan. Metode penelitian menggunakan penelitian kuantitatif pendekatan mixed method oleh Creswell. Data primer diperoleh dari angket dan data sekunder dari wawancara dan dokumentasi. Sampel berjumlah 36 responden dengan teknik purposive sampling. Hasil penelitian menunjukkan bahwa dari sepuluh karakteristik model kepemimpinan yang melayani terdapat tujuh model yang dilaksanakan dengan baik yaitu mendengarkan, menerima orang lain dan empati, kesadaran, membangun kekuatan persuasif, kemampuan melayani, komitmen, dan membangun komunitas. Terdapat tiga model yang perlu ditingkatkan yaitu kemampuan meramalkan, konseptualisasi dan kemampuan menyembuhkan. Model kepemimpinan ini bukanlah sebuah solusi instan mengatasi permasalahan yang dihadapi pemimpin, namun bersifat jangka panjang yang hasilnya memberikan perubahan pencapaian visi dan misi secara komprehensif.
\end{abstract}

Keywords: servant leadersip model, achievement of vision and mission 


\section{A. Pendahuluan}

Kepemimpinan sebenarnya bukanlah sebuah kekuasaan melainkan sebuah amanah, meskipun setiap pemimpin diberi kekuasaan untuk mengatur dan mengarahkan pengikutnya dalam pencapaian tujuan bersama. Kepemimpinan sebagai sebuah amanah mengandung tanggung jawab besar didalamnya dan harus diemban dengan baik. Ditinjau dalam perspektif Islam merupakan amanah dan tanggung jawab yang tidak hanya dipertanggungjawabkan secara horizontal-formal kepada orangorang yang dipimpinnya, tetapi juga akan dipertanggungjawabkan secara vertikal-moral di hadapan Allah SWT.

Realita yang terjadi saat ini ada kecenderungan terjadi krisis kepercayaan pemimpin dalam berbagai organisasi atau lembaga, termasuk lembaga perguruan tinggi. Beberapa indikator terjadinya krisis kepercayaan kepada pemimpin di lembaga perguruan tinggi antara lain berupa pelayanan yang belum memenuhi harapan, kasus-kasus penyalahgunaan kekuasaan oleh sebagian pemimpin sampai tindak pidana korupsi, kasus-kasus pelanggaran yang melibatkan sebagian pemimpin, serta kemampuan sebagian pemimpin yang kurang mempuni dalam pencapaian visi dan misi yang diemban.

Banyak para pemimpin yang hanya bisa berbicara dalam tataran konsep, tetapi sedikit yang mampu melaksanakannya. Kebijakankebijakan atau tindakan-tindakan yang mereka ambil pun lebih cenderung pada solusi instan terhadap permasalahan yang saat itu mereka hadapi, bukan pada penyelesaian masalah secara komprehensif. Padahal menjadi seorang pemimpin mampu berpikir dan mempertimbangkan untuk menentukan siapa yang dihadapi, tujuan yang diinginkan, setiap keputusan atau tindakan yang diambil dan bagaimana akibatnya pada situasi sekarang serta konsekuensinya.

Permasalahan di atas berakibat tidak hanya menyebabkan krisis kepercayaan terhadap kredibilitas dari seorang pemimpin, tetapi menyebabkan pula "krisis keteladanan". Kedua faktor ini akan menurunkan atau mengurangi elektabilitasnya yang berkaitan dengan kekuasaan dan pengaruhnya terhadap orang-orang yang dipimpinnya pada arah perubahan. Mengutip pendapat James Hillman (1996) "Character refers to deep structures of personality that are particularly 

Gorontalo

resistant to change". ${ }^{1}$ Karakter seseorang termasuk pemimpin merujuk kepada struktur dalam kepribadian yang sangat resisten terhadap perubahan.

Idealnya kepemimpinan dan kredibilitas tergantung pada hati, bukan hanya otak. Kedua hal tersebut seharusnya ada pada diri setiap pemimpin, tidak hanya cerdas namun juga memiliki hati yang ikhlas untuk memimpin. Tentunya tipe pemimpin seperti ini disebut sebagai pemimpin masa depan. Artinya kepemimpinannya bukan saja untuk saat ini, tetapi investasi masa depan ketika masa kepemimpinan telah berakhir, mengingat jabatan sebagai pemimpin dapat diberi dan diambil kapan saja.

Pepatah mengatakan 'setiap orang ada masanya dan setiap masa ada orangnya'. Jika dikaitkan dengan kepemimpinan, artinya setiap orang yang diberi amanah menjadi pemimpin sudah ditentukan masa waktunya. Jika masanya sudah berakhir pastilah ada pemimpin yang baru atau terpilih lagi menjadi pemimpin karena disenangi banyak orang. Pertanyaannya apakah kepemimpinan mereka yang dulu sama dengan yang baru? Jawabannya tentu berbeda, karena setiap orang memiliki gaya kepemimpinan sesuai dengan tingkah laku atau karakternya, dan kemampuannya dalam memimpin.

Perlu sebuah solusi untuk mengatasi krisis kepemimpinan di perguruan tinggi melalui model kepemimpinan yang cocok dan mampu diterapkan sesuai situasi dan kondisi yang dihadapi dalam memberi pengaruh yang positif dalam pencapaian visi dan misi yang diemban yaitu dengan kepemimpinan yang melayani.

Kepemimpinan yang melayani adalah gaya kepemimpinan yang menekankan pada pentingnya aspirasi untuk organisasi daripada ambisi untuk orang tertentu, adanya kerendahan hati, kolaborasi, dan bekerja mengarah ke hasil positif. Hal ini menunjukkan bahwa dalam kepemimpinan melayani tidak hanya melihat gaya kepemimpinan, tetapi filsafat hidup. $^{2}$

Berawal dari karya terkenal Greenlaf (1970) kepemimpinan yang melayani adalah pendekatan yang paradoksal tentang kepemimpinan,

\footnotetext{
${ }^{1}$ Larry C. Spears, "Character and Servant Leadership: Ten Characteristics of Effective, Caring Leaders", The Journal of Virtues \& Leadership, Vol. 1 Iss. 1, (2010), pp. 25-30. ${ }^{2}$ Richard H. Savel and Cindy L. Munro, "Character and Servant Leadership: Ten Characteristics of Effective, Caring Leaders", American Journal of Critical Care, March vol. 26 no. 2, (2017), pp. 97-99.
} 
karena menantang keyakinan tradisional tentang kepemimpinan dan pengaruh. Kepemimpinan yang melayani menekankan pada pemimpin seharusnya memperhatikan kebutuhan-kebutuhan para pengikut, memberdayakan mereka, dan membantu mereka mengembangkan kapasitasnya secara penuh dalam pencpaian tujuan organisasi. ${ }^{3}$

Kepemimpinan yang melayani dapat mewujudkan kepemimpinan yang efektif. Para peneliti mengindikasikan bahwa sebenarnya pemimpin yang melayani dapat dibentuk atau diciptakan (nurture) lewat berbagai pelatihan dan pengalaman dalam kurun waktu tertentu di masa hidupnya. Lantu, Pesiwarissa, \& Rumahorbo (2007), mengatakan: "seorang pemimpin yang bukanlah seorang yang telah dilahirkan untuk itu, tetapi diperlukan kerja keras dan lingkungan yang tepat untuk dapat belajar serta bertumbuh menjadi pemimpin yang efektif". Artinya perilaku kepribadian itu dapat dipelajari dan terus dikembangkan dengan tekad yang kuat. ${ }^{4}$

Mencermati berbagai penelitian di atas, menunjukkan bahwa para peneliti tentang kepemimpinan menjadikan kepemimpinan yang melayani menjadi isu-isu penelitian yang penting untuk diterapkan oleh para pemimpin dalam dunia pendidikan di Indonesia, termasuk pada Perguruan Tinggi Keagamaan Islam Negeri (PTKIN) tak terkecuali Fakultas Ilmu Tarbiyah dan Keguruan IAIN Sultan Amai Gorontalo.

Tujuan utama penelitian adalah menganalisis model kepemimpinan yang melayani dalam pencapaian visi dan misi Fakultas Ilmu Tarbiyah dan Keguruan IAIN Sultan Amai Gorontalo yang difokuskan pada karakteristik model kepemimpinan yang dinyatakan oleh Greenleaf dalam Spears (1996) yang berpandangan bahwa yang dilakukan pertama kali oleh seorang pemimpin besar adalah melayani orang lain. Kepemimpinan yang sejati timbul dari mereka yang motivasi utamanya adalah keinginan menolong orang lain.

Penelitian ini memiliki karakteristik yang membedakan dari penelitian-penelitian sebelumnya yang membahas tentang kepemimpinan yang melayani. Banyak penelitian yang ditemukan membahas tentang penerapan model kepemimpinan yang melayani di sekolah, instansi/kantor dan maupun perusahaan. Namun pada lembaga

\footnotetext{
${ }^{3}$ Peter G. Northouse, Kepemimpinan Teori dan Praktik. (Jakarta: Indeks, 2013).

${ }^{4}$ Handita Sari, "Kepemimpinan yang Melayani di Sekolah Menengah Tingkat Atas Swasta Kota Salatiga", Jurnal Manajemen Pendidikan Volume: 3, No. 2, Juli-Desember (2016), pp. 265-276.
} 
pendidikan Islam terutama PTKIN pada umumnya dan Fakultas Ilmu Tarbiyah dan Keguruan pada khususnya belum ditemukan, sehingga penelitian ini memenuhi unsur kebaharuan dan diharapkan menambah khasanah dan wawasan kepemimpinan di lembaga pendidikan Islam.

Jenis penelitian adalah penelitian kuantitatif pendekatan mixed method dengan prosedur yang dikembangkan oleh Creswell et. all (2003) yaitu menggabungkan (integrating), menghubungkan (connecting) dan menancapkan (embedding). ${ }^{5}$ Dengan pendekatan ini diperoleh deskripsi empirik tentang permasalahan yang diteliti.

Subjek penelitian ini adalah para responden yang terdiri dari wakil dekan, ketua jurusan, sekretaris jurusan, dosen dan pegawai di lingkungan Fakultas Ilmu Tarbiyah dan Keguruan IAIN Sultan Amai Gorontalo yang berjumlah 36 responden dengan menggunakan teknik purposive sampling dengan pertimbangan untuk memperoleh data yang valid ditentukan sesuai dengan persyaratan atau tujuan penelitian. Data dikumpulkan melalui angket sebagai data primer dengan menggunakan skala Guttman untuk mendapatkan jawaban yang tegas dari responden yaitu 'ya' dan 'tidak'. Sementara data sekunder diperoleh melalui wawancara dan dokumentasi sebagai data sekunder. Analisis data penelitian terlebih dahulu dianalisis secara statistik deskriptif, selanjutnya didukung dengan analisis kualitatif deskriptif dari hasil wawancara untuk mendukung hasil temuan.

\section{B. Profil singkat tempat penelitian}

Temuan difokuskan pada pembahasan analisis model kepemimpinan yang melayani dari sepuluh karakteristik dominan kepemimpinan yang melayani ditulis oleh Greenleaf dalam Spears (1996) yaitu: mendengarkan, menerima orang lain dan empati, kemampuan meramalkan, kesadaran, membangun kekuatan persuasif, konseptualisasi, kemampuan menyembuhkan, kemampuan melayani, komitmen terhadap pengembangan individu dan institusi, dan membangun komunitas dalam pencapaian visi dan misi Fakultas Ilmu Tarbiyah dan Keguruan IAIN Sultan Amai Gorontalo berdasarkan hasil angket yang diberikan kepada responden yaitu wakil dekan, ketua

\footnotetext{
${ }^{5}$ John W. Creswell, Research Design (Pendekatan Kualitatif, Kuantitatif, dan Mixed). (Yogyakarta: Pustaka Pelajar, 2013).
} 
jurusan dan sekretaris jurusan, dosen dan pegawai serta didukung hasil wawancara dengan hasil temuan dideskripsikan sebagai berikut.

Penelitian ini dilakukan di salah satu fakultas yang ada di IAIN Sultan Amai Gorontalo yaitu Fakultas Ilmu Tarbiyah dan Keguruan. Fakultas ini awal berdirinya bernama Fakultas Tarbiyah IAIN Alauddin di Gorontalo pada tanggal 22 April 1987 dan diresmikan pada tanggal 17 September 1988 oleh Direktur Jenderal Perguruan Tinggi Agama Islam atas nama Menteri Agama RI. Pada tahun 1997 beralih status secara kelembagaan menjadi Sekolah Tinggi Agama Islam Negeri (STAIN) Sultan Amai Gorontalo berdasarkan Keputusan Presiden RI. Nomor 11 tahun 1997 tanggal 21 Maret 1997. Sementara Fakultas Tarbiyah IAIN Sultan Amai Gorontalo yang memiliki 2 Jurusan yaitu Jurusan Pendidikan Agama Islam dan Jurusan Kependidikan Islam. STAIN Sultan Amai Gorontalo kemudian beralih status menjadi Institut Agama Islam Negeri (IAIN) Sultan Amai Gorontalo, berdasarkan Keputusan Presiden RI. No. 91 tanggal 18 Oktober 2004 M bertepatan 10 Ramadhan $1425 \mathrm{H}^{6}$

Berdasarkan Keputusan Menteri Agama Nomor 33 Tahun 2008 tentang STATUTA IAIN Sultan Amai Gorontalo Fakultas Tarbiyah menjadi Fakultas Tarbiyah dan Tadris dan memiliki 4 Jurusan yakni: Jurusan Pendidikan Agama Islam, Jurusan Manajemen Pendidikan Islam, Jurusan Tadris Bahasa Arab, Jurusan Tadris Bahasa Inggris.

Tahun 2013 Fakultas Tarbiyah dan Tadris berubah nomenklatur menjadi Fakultas Ilmu Tarbiyah dan Keguruan dan memiliki 6 Jurusan yaitu: Pendidikan Agama Islam (PAI), Manajemen Pendidikan Islam, Pendidikan Bahasa Arab (PBA), Tadris Bahasa Inggris (TBI), Pendidikan Guru Madrasah Ibtidaiyah (PGMI), dan Pendidikan Guru Raudhatul Athfal (PGRA). Pada tahun 2017 ini Jurusan Pendidikan Guru Raudhatul Athfal (PGRA) menjadi Jurusan Pendidikan Islam Anak Usia Dini (PIAUD).

Sepanjang sejarah, tokoh-tokoh yang pernah memimpin Fakultas Ilmu Tarbiyah dan Keguruan IAIN Sultan Amai Gorontalo, antara lain:

\footnotetext{
${ }^{6}$ IAIN Sultan Amai Gorontalo. Profil Fakultas Ilmu Tarbiyah dan Keguruan. Diakses pada tanggal 16 Pebruari 2017 dari www://iaingorontalo.ac.id
} 
1. Drs. Mohamad Banani

2. Drs. Abdurahman Getteng

3. Drs. Muhammad N. Tuli

4. Drs. H. Djafar Massa

5. Drs. Muhammad N. Tuli, 1986)

6. M.Ag.

Dra. Satria M.A. Koni

7.

Drs. Abdulkarim Rauf

8.

Drs. Yusuf Mopangga, M.Pd.

9.

Drs. Yusuf Mopangga, M.Pd.

10.

11.

12.

Drs. H. Buhari Luneto, M.Pd.

Dr. Lukman Arsyad, M.Pd.

Dr. Mujahid Damopolii, M.Pd 1978) 1981)
Kuasa Dekan Fakultas Tarbiyah IAIN Alauddin di Gorontalo (1969-

Kuasa Dekan Fakultas Tarbiyah IAIN Alauddin di Gorontalo (1978-

Kuasa Dekan Fakultas Tarbiyah IAIN Alauddin di Gorontalo (1981-

Dekan Fakultas Tarbiyah IAIN Alauddin di Gorontalo (1986-1995) Dekan Fakultas Tarbiyah IAIN Alauddin di Gorontalo (1996-1997) Ketua Jurusan Fakultas Tarbiyah STAIN Sultan Amai Gorontalo (1997-2002)

Ketua Jurusan Fakultas Tarbiyah STAIN Sultan Amai Gorontalo (2002-2004)

Ketua Jurusan Fakultas Tarbiyah dan Tadris STAIN Sultan Amai Gorontalo (2004-2005)

Pjs. Dekan Fakultas Tarbiyah dan Tadris(2005-2007)

Dekan Fakultas Tarbiyah dan Tadris (2007-2010)

Dekan Fakultas Tarbiyah dan Tadris (2010-2015)

Dekan Fakultas Ilmu Tarbiyah dan Keguruan (2015- hingga sekarang).

Fakultas Ilmu Tarbiyah dan Keguruan memiliki visi: "Menyiapkan tenaga pendidikan dan kependidikan yang unggul dalam studi Islam, Sains, dan Budaya di Kawasan Timur Indonesia Tahun 2020".

Visi tersebut dijabarkan dalam misi: 1) Mengembangkan pendidikan dan pengajaran, penelitian, dan pengabdian kepada masyarakat yang memiliki keunggulan kompetitif dalam studi Islam, 
Sains dan Budaya; 2) Mengembangkan Jurusan dan Program studi yang unggul dalam studi Islam, Sains dan Budaya; 3) Mengembangkan kerjasama yang unggul dengan lembaga-lembaga keilmuan, kebudayaan Islam dan Teknologi dalam dan luar negeri; 4) Mengembangkan kualitas sumber daya manusia pendidikan yang unggul melalui pelayanan prima; 5) Mengembangkan pelayanan prima menuju good governance.

\section{Model Kepemimpinan Ideal Pada Fak Tarbiyah dan Keguruan}

Karakteristik responden perlu untuk diketahui terkait sebagai subjek dalam penelitian. Karakteristik responden dalam penelitian ini meliputi jenis kelamin dan pendidikan berdasarkan gelar dan jenjang pendidikan pada tabel berikut.

\begin{tabular}{|c|c|c|c|c|c|c|c|c|}
\hline \multirow{2}{*}{ No } & \multirow{2}{*}{$\begin{array}{c}\text { Responde } \\
\mathrm{n}\end{array}$} & \multicolumn{2}{|c|}{$\begin{array}{c}\text { Jenis } \\
\text { Kelamin }\end{array}$} & \multicolumn{4}{|c|}{$\begin{array}{l}\text { Gelar Akademik/ } \\
\text { Jenjang Pendidikan }\end{array}$} & \multirow{2}{*}{$\begin{array}{c}\text { Jumlah } \\
\text { Responden }\end{array}$} \\
\hline & & $\mathrm{L}$ & $\mathrm{P}$ & $\begin{array}{l}\text { Diploma } \\
\text { D1, II, III }\end{array}$ & $\begin{array}{l}\text { Sarjana } \\
\text { (S1) }\end{array}$ & $\begin{array}{c}\text { Magister } \\
\text { (S2) }\end{array}$ & $\begin{array}{c}\text { Doktor } \\
\text { (S3) }\end{array}$ & \\
\hline 1 & $\begin{array}{l}\text { Wakil } \\
\text { Dekan }\end{array}$ & 1 & 2 & 0 & 0 & 0 & 3 & 3 \\
\hline 2 & $\begin{array}{l}\text { Ketua } \\
\text { Jurusan }\end{array}$ & 3 & 3 & 0 & 0 & 1 & 5 & 6 \\
\hline 3 & Sekretaris & 2 & 4 & 0 & 0 & 5 & 1 & 6 \\
\hline 4 & Pegawai & 4 & 5 & 1 & 7 & 1 & 0 & 9 \\
\hline 5 & Dosen & 4 & 8 & 0 & 0 & 5 & 7 & 12 \\
\hline & Total & 14 & 22 & 1 & 7 & 12 & 16 & 36 \\
\hline
\end{tabular}

Terkait hasil temuan model kepemimpinan yang melayani dalam pencapaian visi dan misi FITK IAIN Sultan Amai Gorontalo berdasarkan respon dari 36 responden dideskripsikan sebagai berikut.

\section{a. Mendengarkan (Listening receptively to what others have to say)}

Konsep pemimpin sebagai pelayan, harus berusaha mengenali dan memahami dengan jelas keinginan banyak orang dan bersikap menjadi pendengar yang baik dalam memahami apa yang dikomunikasikan oleh raga, jiwa dan pikiran. Karakteristik model kepemimpinan yang dimaksud disini mengenali dan memahami dengan jelas keinginan dan kebutuhan bawahan, mendengarkan sepenuh hati dan memahami apa yang dikomunikasikan para bawahan dengan tulus, tanggap terhadap keluhan dan pendapat yang disampaikan para bawahan dan berusaha 
membantu setiap bawahan jika mengalami kesulitan dalam bekerja.

Data hasil temuan diperoleh gambaran bahwa dari 36 responden terdapat 33 responden atau 92\% menyatakan jawaban 'ya' dan 3 responden atau $8 \%$ menyatakan 'tidak' dalam mengenali dan memahami dengan jelas keinginan dan kebutuhan bawahan yang terkait dengan hak dan kewajibannya, mendengarkan dan memahami apa yang dikomunikasikan para bawahan dengan tulus dan sepenuh hati. Sementara tanggap terhadap keluhan dan pendapat yang disampaikan para bawahan terdapat 14 responden atau 39\% menyatakan jawaban 'ya' dan 22 responden atau $61 \%$ menyatakan 'tidak'. Sedangkan respon yang diberikan terkait pernyataan pimpinan berusaha membantu setiap bawahan jika mengalami kesulitan dalam bekerja terdapat 28 responden atau $78 \%$ menyatakan jawaban 'ya' dan 8 responden atau $22 \%$ menyatakan 'tidak'.

Hasil temuan mengindikasikan bahwa responden memberikan respon positif terhadap kepemimpinan di FITK dalam dalam mengenali dan memahami dengan jelas keinginan dan kebutuhan bawahan, mendengarkan dan memahami apa yang dikomunikasikan para bawahan dengan tulus dan sepenuh hati, serta berusaha membantu setiap bawahan jika mengalami kesulitan dalam bekerja. Namun responden juga memberikan respon negatif terkait ketanggapan pimpinan terhadap keluhan dan pendapat yang disampaikan para bawahan.

Temuan di atas diperkuat hasil wawancara dengan Dekan FITK yang mengungkapkan bahwa sebagai pimpinan di tingkat Fakultas berusaha memposisikan diri sebagai pendengar yang baik jika ingin didengar oleh bawahan, maka harus mendengarkan apapun yang disampaikan baik itu berupa pertanyaan, ide atau gagasan, maupun keluhan atau permasalahan dan tentunya membutuhkan pemahaman tentang isi, maksud dan tujuan dari apa yang disampaikan oleh bawahan sehingga dapat membantu mencarikan solusi. Temuan negatif meskipun selalu berusaha mendengarkan dan memahami apa yang diinginkan dan dibutuhkan bawahan, namun tidak semuanya dapat dipenuhi sesuai dengan harapan karena terkait dengan pengambilan kebijakan di tingkat institut. $^{7}$

Kepemimpinan yang sudah dilakukan oleh Dekan FITK dalam

\footnotetext{
${ }^{7}$ Mujahid Damopolii, Dekan FITK IAIN Sultan Amai Gorontalo, Wawancara: 4 September 2017.
} 
mendengarkan bawahan menunjukkan bahwa sebagai pemimpin telah melaksanakan fungsi konsultasi dalam kepemimpinannya. Fungsi ini secara teori bersifat komunikasi dua arah, dimana pemimpin kerapkali memerlukan bahan pertimbangan, yang mengharuskannya berkonsultasi dengan orang-orang yang dipimpinnya dalam menetapkan keputusan. ${ }^{8}$ Pemimpin tidak saja memikirkan bagaimana mempekerjakan anggotanya secara bertanggung jawab, tetapi juga peduli dengan harapan, kebutuhan dan aspirasi pengembangannya. ${ }^{9}$

\section{b. Menerima orang lain dan Empati (Acceptance of others and having empathy for them)}

Pemimpin yang sukses adalah mereka yang mampu menjadi pendengar dengan penuh empati kepada setiap orang tanpa pandang bulu, dan menerima serta mengakui keberadaan orang lain dengan segala kelebihan dan kekurangannya, meskipun keberadaan orang tersebut tidak diinginkan. Karakteristik model kepemimpinan yang dimaksud disini adalah menghargai hasil kerja bawahannya, memberi penghargaan, berkolaborasi dan bersinergi dalam menyelesaikan pekerjaan, memperlakukan bawahannya sebagai mitra kerja yang sejajar dalam bekerja dan berempati kepada setiap orang tanpa ada perbedaaan.

Data hasil temuan diperoleh gambaran bahwa dari 36 responden terdapat 36 responden atau 100\% menyatakan jawaban 'ya' menghargai hasil kerja dari setiap wakilnya, pimpinan prodi, dosen dan pegawai, berkolaborasi dan bersinergi dengan wakil dekan, pimpinan prodi, dosen dan pegawai dalam menyelesaikan pekerjaan, pimpinan memperlakukan bawahannya sebagai mitra kerja yang sejajar dalam bekerja, berempati kepada setiap orang tanpa ada perbedaaan jika ada masalah atau mengalami musibah dan tidak ada atau $0 \%$ menyatakan jawaban 'tidak'. Sementara terdapat 30 responden atau $83 \%$ menyatakan jawaban 'ya' memberi penghargaan pada pimpinan prodi, dosen dan pegawai yang memiliki kinerja baik sesuai dengan aturan yang berlaku dan 6 responden atau $17 \%$ menyatakan 'tidak'.

Hasil temuan ini mengindikasikan bahwa model kepemimpinan

\footnotetext{
${ }^{8}$ Imam Machali dan Noor Hamid, Pengantar Manajemen Pendidikan Islam (Perencanaan, Pengorganisasian, dan Pengawasan dalam Pengelolaan Pendidikan Islam). (Yogyakarta: Pustaka An Nur, 2017).

${ }^{9}$ Frans Mardi Hartono, Paradigma Baru Manajemen Indonesia, Menciptakan Nilai dengan Bertumpu Pada Kebajikan dan Potensi Insani,(Bandung: Mizan Pustaka, 2009).
} 
melayani dalam menerima orang lain dan empati oleh pimpinan FITK IAIN Sultan Amai Gorontalo sudah diterapkan dengan baik karena respon dari responden sangat positif yaitu $100 \%$ menyatakan pimpinan menghargai setiap hasil kerja, berkolaborasi dan bersinergi dalam menyelesaikan pekerjaan, memperlakukan bawahannya sebagai mitra kerja dan berempati kepada setiap orang tanpa ada perbedaaan. Sementara 83\% responden menyatakan memberi penghargaan pada pimpinan prodi, dosen dan pegawai yang memiliki kinerja baik.

Memperkuat hasil temuan di atas, dilakukan wawancara dengan Dekan FITK diperoleh informasi bahwa sebagai pimpinan selalu berusaha mengapresiasi setiap pekerjaan yang dilakukan oleh wakil dekan, ketua jurusan bersama sekretarisnya, para dosen dan pegawai, dengan senantiasa menjalin silaturahmi dan kekeluargaan dengan siapa pun agar ada kedekatan emosional tanpa ada GAP, memberi penghargaan atas setiap hasil kerja tidak harus berbentuk benda melainkan pujian membuat setiap orang merasa dihargai keberadaannya. Untuk mengapresiasi kerja dosen pada setiap kegiatan yudisium sarjana dilakukan pemilihan dosen terbaik oleh mahasiswa, bagi dosen yang terpilih diberikan penghargaan. Demikian halnya bagi mahasiswa setiap yudisium semester bagi mereka yang memiliki Indeks Prestasi terbaik diberikan piagam penghargaan untuk memotivasi mahasiswa yang lain berprestasi. Bentuk penghargaan ini ke depan akan ditingkatkan lagi termasuk penghargaan kepada para pegawai sebagai ujung tombak pengelolaan administrasi di tingkat fakultas.

Temuan di atas, mengindikasikan bahwa pimpinan FITK dalam melaksanakan fungsi kepemimpinannya untuk mendapatkan komitmen dari setiap bawahannya dalam pencapaian visi dan misi fakultas dilakukan dengan memberi penghargaan, berkolaborasi dan bersinergi dalam menyelesaikan pekerjaan, memperlakukan bawahannya sebagai mitra kerja dan berempati. Hal ini sejalan dengan teori 'Leaders must win people over before they enlist their'. '11 Para pemimpin harus memenangkan orang-orang sebelum meminta dukungan mereka. Jika ingin mendapatkan sesuatu yang produktif dari bawahan, sebagai pemimpin harus mampu menghargainya.

\footnotetext{
${ }^{10}$ Mujahid Damopolii, Dekan FITK IAIN Sultan Amai Gorontalo, Wawancara: 4 September 2017.

${ }^{11}$ Clay Brewer, "Servant Leadership: A Review of Literature", Online Journal of Workforce Education and Development Volume IV, Issue 2 - Spring (2010), pp. 1-8.
} 


\section{c. Kemampuan meramalkan (foresight and intuition)}

Ada ungkapan yang menyatakan bahwa pemimpin adalah "pemimpi" yang mampu mewujudkan mimpi tersebut menjadi nyata. Artinya menjadi pemimpin harus mampu menahkodai ke mana orangorang yang dipimpin akan dibawa menuju kepada perubahan yang lebih baik dengan segala resikonya. Oleh karena itu, menjadi pemimpin harus mampu meramalkan atau memiliki visi yang jelas. Kemampuan meramalkan yang dimaksud disini adalah pimpinan mempunyai visi yang dapat membuat bawahannya menjadi berkembang, melibatkan semua pihak yang terkait dan stakeholder dalam menyusun visi dan misi fakultas, memiliki pengetahuan dan keterampilan untuk menyelesaikan segala sesuatu, memberikan pandangan masa depan fakultas yang jelas, mampu mengubah hal negatif menjadi positif (ancaman menjadi peluang).

Data hasil temuan diperoleh gambaran bahwa dari 36 responden terdapat 28 responden atau $78 \%$ menyatakan jawaban 'ya' pimpinan mempunyai visi yang dapat membuat bawahannya menjadi berkembang dan termotivasi dalam melaksanakan pekerjaannya dan 8 responden atau $22 \%$ menyatakan 'tidak'. Terdapat 26 responden atau $67 \%$ menyatakan jawaban 'ya' melibatkan semua pihak yang terkait dan stakeholder dalam menyusun visi dan misi fakultas dan 12 responden atau 33\% menyatakan 'tidak'. Terdapat 31 responden atau $86 \%$ menyatakan jawaban 'ya' pimpinan memiliki pengetahuan dan keterampilan untuk menyelesaikan segala sesuatu serta memberikan pandangan masa depan fakultas yang jelas dan hanya 5 responden atau 14\% menyatakan 'tidak'. Terdapat 18 responden atau $50 \%$ menyatakan jawaban 'ya' pimpinan mampu mengubah hal negatif menjadi positif (ancaman menjadi peluang) dan selebihnya 18 responden atau 50\% menyatakan 'tidak'. Hasil temuan ini mengindikasikan bahwa karakteristik model kepemimpinan yang melayani dalam hal kemampuan meramalkan oleh pimpinan FITK IAIN Sultan Amai Gorontalo yang masih perlu untuk ditingkatkan dengan baik, karena sebagian responden menyatakan 'ya' dan masih ada sebagian yang menyatakan 'tidak'.

Terkait hasil temuan ini, dilakukan wawancara dengan Dekan FITK yang mengungkapkan bahwa pimpinan juga sebagai manusia biasa yang tentunya tidak lepas dari kekurangan maupun keterbatasan. Selama 
menjadi Dekan FITK telah banyak dibantu oleh tim kerja yang ada di fakultas, serta mempercayakan tim untuk bekerja dengan efektif dan efisien. Selama ini fakultas masih terkendala dalam menghadirkan stakeholder, alumni dan pengguna alumni pada saat diadakan workshop yang berkaitan dengan perumusan visi dan misi fakultas maupun dalam redesain kurikulum karena faktor kesibukan, sehingga perlu dirancang kegiatan bersama yang dapat mewujudkan kegiatan tersebut. Terkait dengan kemampuan mengubah hal negatif menjadi positif (ancaman menjadi peluang) tidak seperti membalikkan telapak tangan semuanya butuh proses dan tidak instan karena dalam tataran praktiknya tidak lepas dari dinamika organisasi, sehingga harus terus belajar dan meningkatkan kemampuan dalam mengatasi setiap dinamika yang ada. ${ }^{12}$

Mencermati hasil temuan yang ada terkait dengan kemampuan meramalkan menunjukkan bahwa setidaknya Dekan selaku pimpinan FITK telah berusaha melaksanakannya dengan segala kemampuan dan keterbatasan untuk mewujudkan mimpi besar fakultas. Hal ini sejalan dengan penelitian Sulisworo bahwa untuk mencapai mimpi besar dari organisasi sangat tergantung dari kemampuan pemimpin memprediksi masa depan, merumuskan dan mengartikulasi visi yang realistik, kredibel, serta mengkomunikasikan visi ke depan, yang menekankan pada keharmonisan hubungan manusia dan mampu menstimulasi secara intelektual dan arif bagi anggota untuk mewujudkan visi organisasi, serta mampu memberikan arahan, tujuan, peran, dan tugas kepada seluruh unsur dalam perguruan tinggi.

\section{d. Kesadaran (Awareness and perception)}

Kesadaran yang dimiliki seorang pemimpin memperkuat model kepemimpinan yang melayani. Kesadaran yang dimaksud disini adalah pimpinan mengedepankan kejujuran dan kedisiplinan dalam bekerja, memberikan tanggung jawab untuk membuat keputusan penting dalam pekerjaan, menjadi teladan dan contoh terhadap perilaku yang diinginkan, senantiasa membuat dirinya berguna setiap saat dan mampu menciptakan kebersamaan.

Data hasil temuan diperoleh gambaran bahwa dari 36 responden

\footnotetext{
${ }^{12}$ Mujahid Damopolii, Dekan FITK IAIN Sultan Amai Gorontalo, Wawancara: 4 September 2017.

${ }^{13}$ Sulisworo D, "Model Kepemimpinan Modern di Program Pascasarjana Universitas Ahmad Dahlan”, Journal of Education and Learning. Vol.6 No.1 (2012) pp. 43-50.
} 
terdapat 38 responden atau $100 \%$ menyatakan jawaban 'ya' pimpinan mengedepankan kejujuran dan kedisiplinan dalam bekerja, memberikan tanggung jawab untuk membuat keputusan penting dalam pekerjaan, menjadi teladan dan contoh terhadap perilaku yang diinginkan, senantiasa membuat dirinya berguna setiap saat dan mampu menciptakan kebersamaan, dan $0 \%$ yang menyatakan jawaban 'tidak'.

Hasil temuan ini sangat positif dan menunjukkan bahwa karakteristik model kepemimpinan yang melayani dalam hal kesadaran sebagai pimpinan FITK IAIN Sultan Amai Gorontalo dinilai oleh responden sangat baik. Temuan ini dikonfirmasi melalui wawancara dengan Dekan FITK yang mengungkapkan bahwa patut disyukuri sebagai pimpinan di Fakultas dapat bekerjasama dengan seluruh perangkat yang ada di fakultas. Prinsip yang selalu disampaikan setiap pertemuan atau rapat adalah setiap keberhasilan merupakan keberhasilan "kita" bukan keberhasilan "saya" atau "kami". Sementara jika terjadi kegagalan adalah kegagalan "saya" karena tanggungjawab penuh ada pemimpin. Untuk dapat menumbuhkan dan meningkatkan kesadaran tim kerja tentunya harus berupaya memberikan teladan dan contoh yang baik, dan juga jangan malu untuk belajar kepada sesepuh yang dituakan, karena menjadi pemimpin bukanlah orang yang merasa pintar namun pintar merasa dalam menciptakan kebersamaan.

Mencermati hasil temuan yang ada terkait dengan kesadaran menunjukkan bahwa Dekan selaku pimpinan FITK memiliki kesadaran yang tinggi sebagai pemimpin. Hal ini dibuktikan dengan respon positif dari responden yang menyatakan pimpinan mengedepankan kejujuran dan kedisiplinan dalam bekerja, memberikan tanggung jawab untuk membuat keputusan penting dalam pekerjaan, menjadi teladan dan contoh terhadap perilaku yang diinginkan, senantiasa membuat dirinya berguna setiap saat dan mampu menciptakan kebersamaan. Temuan ini sejalan dengan teori yang dikemukakan Brown et al (2005) bahwa servant leadership can also be related to the more recent work on ethical leadership. ${ }^{15}$ Kepemimpinan yang melayani terkait dengan pekerjaan pada kepemimpinan etika yang lebih mengedepankan pada kesadaran diri

\footnotetext{
${ }^{14}$ Mujahid Damopolii, Dekan FITK IAIN Sultan Amai Gorontalo, Wawancara: 4 September 2017.

${ }^{15}$ Dirk van Dierendonck and Inge Nuijten, "The Servant Leadership Survey: Development and Validation of a Multidimensional Measure", Journal of Business and Psychology. Sept; 26 (3) (2011) pp. 249-267.
} 

Gorontalo

sebagai orang yang diteladani dan diikuti.

\section{e. Membangun kekuatan Persuasif (Having highly develoved power of persuasion)}

Karakter dari kepemimpinan yang melayani adalah persuasif dalam setiap proses pengambilan keputusan ketimbang memaksakan kehendak. Hal ini akan memberi rasa nyaman bagi tim kerja, karena merasa selalu dihargai keberadaannya. Membangun kekuatan persuasif yang dimaksud disini adalah pimpinan saat rapat atau pertemuan tidak mengambil keputusan secara sepihak namun memberikan kesempatan bawahannya untuk memberi masukan, mempertimbangkan berbagai masukan sebelum mengambil suatu keputusan, tidak memaksakan kehendaknya.

Data hasil temuan diperoleh gambaran bahwa dari 36 responden terdapat 38 responden atau 100\% menyatakan jawaban 'ya' pimpinan saat rapat tidak mengambil keputusan secara sepihak namun memberikan kesempatan bawahannya untuk memberi masukan, mempertimbangkan berbagai masukan sebelum mengambil suatu keputusan, tidak memaksa para bawahannya untuk mengikuti kehendaknya dan $0 \%$ yang menyatakan jawaban 'tidak'.

Hasil temuan ini sangat positif dan menunjukkan bahwa karakteristik model kepemimpinan yang melayani dalam membangun kekuatan persuasif oleh pimpinan FITK IAIN Sultan Amai Gorontalo juga dinilai oleh responden sangat baik. Temuan ini dikonfirmasi melalui wawancara dengan Dekan FITK yang menyatakan bahwa setiap pengambilan keputusan di tingkat fakultas berdasarkan keputusan bersama melalui hasil rapat dengan tim kerja terkait, terutama dengan pihak jurusan selalu mempertimbangkan berbagai masukan di masingmasing jurusan. Jika memberi kesempatan kepada tim kerja dalam memberi masukan terkait pengambilan keputusan telah memberi mereka kesempatan untuk berkembang dan bertanggung jawab. Membuat orang bertanggungjawab adalah memberi kesempatan menggapai mimpi besar FITK, dan hal itu dimulai dari hal-hal yang kecil. ${ }^{16}$

Mencermati hasil temuan di atas menunjukkan bahwa Dekan selaku pimpinan FITK memiliki kemampuan yang sangat baik membangun kekuatan persuasif dalam pencapaian visi dan misi fakultas.

\footnotetext{
${ }^{16}$ Mujahid Damopolii, Dekan FITK IAIN Sultan Amai Gorontalo, Wawancara: 4 September 2017.
} 
Temuan ini sejalan dengan pendapat Robert bahwa The healthy organization is an organization in which the characteristics of servantleadership are displayed through the organizational culture and are valued and practiced by the leadership and workforce. ${ }^{17}$ Organisasi yang sehat adalah sebuah organisasi yang menerapkan karakteristik dari kepemimpinan yang melayani melalui budaya yang saling menghargai dan dipraktekkan oleh pemimpin dan pekerjanya.

\section{f. Konseptualisasi (An ability to conceptualize and to communicate concepts)}

Seorang pemimpin yang melayani memiliki pola pikir konseptual di dalam perannya sebagai seorang pemimpin. Konseptualisasi yang dimaksud disini adalah pimpinan memiliki ide-ide kreatif untuk kemajuan fakultas, mampu mendesain program jangka pendek dan jangka panjang pengembangan fakultas, dan mampu mengidentifikasi persoalan-persoalan yang ada.

Data hasil temuan diperoleh gambaran bahwa dari 36 responden terdapat 20 responden atau 56\% menyatakan jawaban 'ya' pimpinan memiliki ide-ide kreatif untuk kemajuan fakultas dan 16 responden atau $44 \%$ yang menyatakan jawaban 'tidak'. Terdapat 20 responden atau $56 \%$ menyatakan jawaban 'ya' pimpinan mampu mendesain program jangka pendek dan jangka panjang pengembangan fakultas, dan mampu mengidentifikasi persoalan-persoalan yang ada. Selebihnya terdapat 16 responden atau 44\% yang menyatakan jawaban 'tidak'.

Hasil temuan ini menunjukkan bahwa karakteristik model kepemimpinan yang melayani terkait konseptualisai pimpinan FITK IAIN Sultan Amai Gorontalo sudah diterapkan dengan cukup baik. Temuan ini dikonfirmasi melalui wawancara dengan Dekan FITK yang menyatakan bahwa desain program jangka pendek dan jangka pangjang fakultas sudah tertuang dalam renstra dan disusun bersama tim kerja, namun capaiannya tidak langsung terlihat secara komprehensif, namun secara bertahap dan selalu dibenahi melalui kegiatan raker fakultas sekaligus evaluasi akhir tahun apa saja program yang sudah dilaksanakan

\footnotetext{
${ }^{17}$ Dirk van Dierendonck and Inge Nuijten, "The Servant Leadership Survey: Development and Validation of a Multidimensional Measure", Journal of Business and Psychology. Sept; 26 (3) (2011) pp. 249-267.
} 
dan rencana program yang akan dilaksanakan. ${ }^{18}$

Hasil temuan di atas menunjukkan bahwa Dekan selaku pimpinan FITK perlu untuk meningkatkan model kepemimpinan ini dalam pencapaian visi dan misi fakultas, dalam hal mendesain program jangka pendek dan jangka panjang yang lebih realistis sesuai dengan kebutuhan fakultas dengan target capaian yang jelas, serta mengidentifikasi penyebab persoalan-persoalan yang ada, untuk dicarikan solusi penyelesaiannya. Hal ini sejalan dengan pendapat Stone, Russell \& Patterson (2004) bahwa: servant leaders trust followers to act in the best interests of the organization and focus on those followers rather than the organizational objectives. ${ }^{19}$ Pemimpin yang melayani percaya pengikut untuk bertindak dalam kepentingan terbaik organisasi dan fokus pada pengikut daripada tujuan organisasi.

\section{g. Kemampuan Menyembuhkan (ability to exert a healing influence upon individual and institutions)}

Kemampuan menyembuhkan merupakan karakter yang harus dimiliki oleh tipe pemimpin yang melayani. Seorang pemimpin dapat menyembuhkan luka batin, traumatik dari kegagalan sebelumnya, atau dapat memberikan semangat kembali, memberikan energi yang positif bagi tim-nya agar tetap semangat dan fokus bekerja. Kemampuan menyembuhkan yang dimaksud disini adalah menggerakkan hati dan memberi semangat kerja, mampu mengembalikan motivasi kerja, mengevaluasi diri dan tidak menyalahkan orang lain.

Data hasil temuan diperoleh gambaran bahwa dari 36 responden terdapat 25 responden atau $69 \%$ menyatakan jawaban 'ya' menggerakkan hati dan memberi semangat kerja, serta mengembalikan motivasi kerja dan 11 responden atau $31 \%$ yang menyatakan jawaban 'tidak'. Sementara terkait pernyataan mengevaluasi diri dan tidak menyalahkan orang lain terdapat 36 responden atau 100\% menyatakan jawaban 'ya' dan $0 \%$ yang menyatakan jawaban 'tidak'.

Hasil temuan ini menunjukkan bahwa karakteristik model kepemimpinan yang melayani terkait konseptualisai pimpinan FITK

\footnotetext{
${ }^{18}$ Mujahid Damopolii, Dekan FITK IAIN Sultan Amai Gorontalo, Wawancara: 4 September 2017.

${ }^{19}$ David E. Melchar and Susan m. Bosco, “Achieving High Organization Performance through Servant Leadership", The Journal of Business Inquiry Vol. 9, No.1, (2010), pp. 74-88.
} 
IAIN Sultan Amai Gorontalo sudah diterapkan dengan cukup baik, karena masih terdapat $31 \%$ yang menyatakan bahwa pimpinan belum mampu menggerakkan hati, memberi semangat kerja, dan belum mampu mengembalikan motivasi kerja yang hilang. Temuan ini dikonfirmasi melalui wawancara dengan Dekan FITK menyatakan bahwa yang menjadi kendalanya dalam menggerakkan hati, memberi semangat kerja dan meningkatkan motivasi kerja adalah adanya keinginan dan kebutuhan yang berbeda-beda dengan karakter yang berbeda pula sehingga menyulitkan dalam memenuhi semua apa yang diinginkan, seperti halnya dalam memenuhi kebutuhan dosen terkait dengan penyediaan LCD di masing-masing kelas, belum sepenuhnya dapat dipenuhi karena terkait dengan penganggaran yang ada. Di samping itu, motivasi kerja bersifat dorongan dari diri sendiri, maka tentunya dikembalikan kepada kesadaran diri yang bersangkutan. ${ }^{20}$

Hasil temuan di atas menunjukkan bahwa Dekan selaku pimpinan FITK perlu untuk meningkatkan model kepemimpinan ini dalam pencapaian visi dan misi fakultas terutama memberikan perhatian terhadap apa yang diinginkan bawahannya, sehingga mereka memiliki kepuasan daalam bekerja dan akan termotivasi bekerja sesuai dengan harapan. Hal ini sangat penting karena bekerja adalah suatu bentuk aktivitas fisik dan mental yang bertujuan untuk mendapatkan kepuasan. Temuan ini sejalan dengan studi yang dilakukan Avolio et al, (2000) yang menunjukkan bahwa kepemimpinan yang melayani berkorelasi dengan kepuasan kerja secara intrinsik dalam hal mengembalikan motivasi kerja dan komitmen pada organisasi. ${ }^{21}$

\section{h. Kemampuan Melayani (Ability to serve)}

Model dari karakter ini adalah seorang pemimpin yang melayani adalah memiliki kemampuan sebagai pelayan yang memegang teguh amanah yang diberikan sesuai dengan peran dan tanggung jawabnya. Kemampuan melayani yang dimaksud disini adalah memberikan kesempatan secara terbuka untuk memberikan kritik dan ide-ide baru demi kemajuan fakultas, rendah hati dan tidak mengharapkan

\footnotetext{
${ }^{20}$ Mujahid Damopolii, Dekan FITK IAIN Sultan Amai Gorontalo, Wawancara: 4 September 2017.

${ }^{21}$ Wekesa S. Olesia, G.S. Namusonge and Mike E. Iravo, “Achieving High Organization Performance through Servant Leadership Role of Servant Leadership on Organizational Commitment: An Exploratory Survey of State Corporations in Kenya", International Journal of Humanities and Social Science, July, Vol. 3 No. 13, (2013), pp. 85-94.
} 
penghormatan dalam memimpin, mendelegasikan hal-hal penting kepada wakil-wakilnya apabila ada tugas keluar, serta memperlakukan setiap orang dengan penuh rasa hormat dan melayaninya dengan setulus hati.

Data hasil temuan diperoleh gambaran bahwa dari 36 responden terdapat 38 responden atau 100\% menyatakan jawaban 'ya' pimpinan memberikan kesempatan secara terbuka untuk memberikan kritik dan ide-ide baru demi kemajuan fakultas, rendah hati dan tidak mengharapkan penghormatan dalam memimpin, mendelegasikan hal-hal penting kepada wakil-wakilnya apabila ada tugas keluar, serta memperlakukan setiap orang dengan penuh rasa hormat dan melayaninya dengan setulus hati dan $0 \%$ yang menyatakan jawaban 'tidak'.

Hasil temuan ini sangat positif dan menunjukkan bahwa kemampuan melayani oleh pimpinan FITK IAIN Sultan Amai Gorontalo sudah dilakukan sangat baik berdasarkan respon positif dari responden. Temuan ini dikonfirmasi melalui wawancara dengan Dekan FITK menyatakan bahwa sangat mengapresiasi setiap orang dalam memberikan kritik dan ide-ide baru demi kemajuan fakultas dan yang paling penting adalah menghargai keberadaannya, menghargai tugas dan fungsinya, dengan selalu mengajak tim kerja untuk bekerja sama dan sama-sama bekerja demi pengembangan fakultas lebih baik. ${ }^{22}$

Mencermati hasil temuan di atas menunjukkan bahwa Dekan selaku pimpinan FITK memiliki kemampuan melayani yang sangat baik dalam pencapaian visi dan misi fakultas. Temuan ini sejalan dengan pendapat Greenleaf (1977): argued that true leadership is essentially synonymous with service and great leaders are identified by the service they perform for individuals and society. ${ }^{23}$ Pemimpin yang melayani mengutamakan kepentingan yang lebih besar dari komunitas besar dan memerhatikan secara penuh kebutuhan pengikut, peduli dengan orang lain dan menghilangkan diskriminasi.

\footnotetext{
${ }^{22}$ Mujahid Damopolii, Dekan FITK IAIN Sultan Amai Gorontalo, Wawancara: 4 September 2017.

${ }^{23}$ Jack Thomas McCann, Daniel Graves and Lieven Cox, "Servant Leadership, Employee Satisfaction, and Organizational Performance in Rural Community Hospitals", International Journal of Business and Management"; Vol. 9, No. 10, (2014), pp. 28-38.
} 


\section{i. Komitmen terhadap pengembangan individu dan institusi (Commitmen to the growth of people)}

Salah satu karakter dari seorang pemimpin yang melayani adalah komitmen untuk membangun dan pengembangan sumber daya manusia. Komitmen yang dimaksud disini adalah pimpinan memiliki keinginan yang kuat untuk belajar dari orang lain, memberikan kesempatan dalam mengembangkan keilmuwannya, menciptakan iklim kerja yang efektif, menaruh perhatian besar pada pengembangan sumber dayanya.

Data hasil temuan diperoleh gambaran bahwa dari 36 responden terdapat 38 responden atau 100\% menyatakan jawaban 'ya' dan $0 \%$ yang menyatakan jawaban 'tidak'. Hal ini mengindikasikan bahwa pimpinan FITK IAIN Sultan Amai Gorontalo memiliki komitmen yang kuat dalam pengembangan diri dan sumber dayanya. Temuan ini dikonfirmasi melalui wawancara dengan Dekan FITK menyatakan bahwa komitmen dalam pengembangan sumber daya penting untuk dilakukan, karena kemajuan fakultas sangat tergantung pada kemampuan sumber dayanya. Kebijakan yang diterapkan di FITK dalam hubungannya dengan suasana akademik menganut prinsip "bebas, etis dan bertanggungjawab". Prinsip tersebut memberikan peluang terpeliharanya interaksi antara dosen, mahasiswa, dan pegawai, baik di dalam maupun di luar kampus, dan mampu menciptakan iklim yang mendorong perkembangan dan kegiatan akademik/profesional. Seluruh civitas akademik diberikan kebebasan untuk mengembangkan tradisi keilmuan dan kebebasan mimbar akademik, baik di dalam dan di luar kampus, dengan syarat bahwa segala kegiatan keilmuan yang dilakukan harus mengacu kepada kode etik IAIN Sultan Amai Gorontalo dan bertanggungjawab. Kebijakan tersebut berimplikasi terhadap tumbuhnya gairah akademik yang tinggi di kalangan dosen dan mahasiswa. ${ }^{24}$

Temuan ini sejalan dengan studi yang dilakukan Dirk et. al (2017) bahwa hubungan antara tuntutan pekerjaan tuntutan dengan sumber daya yang memadai menjadi studi masa depan yang menarik. Hal ini menyoroti bagaimana pemimpin dapat membuat iklim kerja yang efektif dan budaya kerja yang mendukung pengembangan sumber daya manusianya. ${ }^{25}$

\footnotetext{
${ }^{24}$ Mujahid Damopolii, Dekan FITK IAIN Sultan Amai Gorontalo, Wawancara: 4 September 2017.

${ }^{25}$ Dirk van Dierendonck, Sigrun Gunnarsdóttir and Kathleen A. Patterson, "Review The Functions of a Servant Leader"; Administrative Sciences, Vol.7, No.5; doi:10.3390/admsci7010005, (2017), pp. 1-32.
} 


\section{j. Membangun komunitas di tempat kerja (Building community in the workplace)}

Pemimpin yang melayani selain mampu membangun orang-orang yang terlibat dengannya, juga mampu membangun komunitas di sekelilingnya. Membangun komunitas yang dimaksud disini adalah pimpinan membangun hubungan personal yang kuat, menciptakan lingkungan kerja yang kondusif dengan kerjasama dan saling percaya, memperbaiki keadaan apabila terjadi hubungan yang tidak harmonis, bekerjasama dengan semua pihak, menghargai perbedaan yang ada.

Data hasil temuan diperoleh gambaran bahwa dari 36 responden terdapat 38 responden atau 100\% menyatakan jawaban 'ya' dan $0 \%$ yang menyatakan jawaban 'tidak' terkait pernyataan pimpinan membangun hubungan personal yang kuat, menciptakan lingkungan kerja yang kondusif dengan kerjasama dan saling percaya, memperbaiki keadaan apabila terjadi hubungan yang tidak harmonis, bekerjasama dengan semua pihak, menghargai perbedaan-perbedaan yang ada.

Hasil temuan ini menunjukkan bahwa pimpinan FITK IAIN Sultan Amai Gorontalo memiliki kemampuan membangun komunitas yang baik dalam pencapaian visi dan misi fakultas. Temuan ini dikonfirmasi melalui wawancara dengan Dekan FITK menyatakan bahwa membangun komunitas di tempat kerja merupakan hal yang sangat penting dalam menciptakan kebersamaan dan sinergitas dalam bekerja, sehingga perlu untuk bekerjasama dengan semua pihak bahkan dengan mereka yang kurang mendukung sekalipun. Di samping itu hal yang paling penting adalah memfasilitasi bentuk kerjasama yang dibangun diantara para pimpinan jurusan, dosen dan pegawai dalam menyelesaikan tugasnya. ${ }^{26}$

Temuan ini sejalan dengan pendapat Wong and Davey (2007): servant leadership is a humanistic approach that holds "an optimistic view of employees, believing that they will respond positively to leaders who demonstrate...SL characteristics" and motivates employees "primarily through creating a caring and supportive workplace". ${ }^{27}$ Kepemimpinan yang melayani adalah pendekatan kemanusiaan yang memegang pandangan optimis dan percaya bahwa

\footnotetext{
${ }^{26}$ Mujahid Damopolii, Dekan FITK IAIN Sultan Amai Gorontalo, Wawancara: 4 September 2017.

${ }^{27}$ Joyce W. Fields, Karen C. Thompson and Julie R. Hawkins, "Servant Leadership: Teaching the Helping Professional”, Journal of Leadership Education, DOI: 1012806/V14/I4/R2, (2015), pp. 92-105.
} 
bawahan akan merespon positif terhadap pemimpin yang melayaninya dan memotivasinya dengan menciptakan tempat kerja yang nyaman dan mendukungnya.

\section{Kesimpulan}

Kesimpulan dari penelitian ini adalah model kepemimpinan yang melayani sudah diterapkan dengan baik dalam pencapaian visi dan misi di Fakultas Ilmu Tarbiyah dan Keguruan IAIN Sultan Amai Gorontalo. Hal ini dibuktikan dari respon positif yang diberikan oleh 36 responden lebih tinggi dibandingkan respon negatif terhadap sepuluh karakteristik model kepemimpinan yang melayani dengan data temuan terdapat tujuh model yang dilaksanakan dengan baik yaitu mendengarkan, menerima orang lain dan empati, kesadaran, membangun kekuatan persuasif, kemampuan melayani, komitmen, dan membangun komunitas. Terdapat tiga model yang perlu ditingkatkan yaitu kemampuan meramalkan, konseptualisasi dan kemampuan menyembuhkan.

Pertama, kemampuan meramalkan yang perlu ditingkatkan adalah kemampuan pimpinan mempunyai visi yang dapat membuat bawahannya menjadi berkembang dan termotivasi dalam melaksanakan pekerjaannya. Disamping itu melibatkan semua pihak yang terkait dan stakeholder, alumni serta pengguna alumni dalam menyusun visi dan misi fakultas. Jika hal ini dilakukan tentunya pimpinan Fakultas akan mampu mengubah tantangan menjadi peluang.

Kedua, kemampuan konseptualisasi yang perlu ditingkatkan adalah pimpinan senantiasa memiliki ide-ide kreatif dan berinovasi, meningkatkan kemampuan mendesain program jangka pendek dan jangka panjang, serta mampu mendeteksi persoalan-persoalan yang ada di tingkat prodi, dosen, pegawai dan mahasiswa dalam pengembangan fakultas menjadi lebih baik.

Ketiga, kemampuan menyembuhkan yang perlu ditingkatkan adalah kemampuan pimpinan dalam menggerakkan hati dan memberi semangat pada setiap wakil dekannya, pimpinan prodi, dosen dan pegawai untuk meningkatkan kinerja. Di samping itu terus berusaha mengembalikan motivasi kerja pada bawahan yang hilang dengan menjalin hubungan yang sejati bukan sekedar atasan dengan bawahan.

Berdasarkan karakteristik model kepemimpinan yang melayani mengindikasikan bahwa model kepemimpinan ini sangat cocok diterapkan pada lembaga pendidikan Islam yang tidak lepas dari berbagai 
permasalahan kepemimpinan, kepentingan dan kekuasaan. Model kepemimpinan ini menjadikan pemimpin memiliki figur yang mampu menempatkan bawahannya sebagai manusia seutuhnya atau memanusiakannya sehingga mereka merasa dihargai, sadar, yakin dan bertanggungjawab terhadap apa yang harus dikerjakan tanpa menunggu perintah. Jika ini terwujud lembaga pendidikan Islam akan lebih maju dan mampu bersaing secara kompetitif yang bermuara pada pencapaian visi dan misi yang diemban.

\section{Daftar Pustaka}

Clay Brewer, "Servant Leadership: A Review of Literature", Online Journal of Workforce Education and Development Volume IV, Issue 2 - Spring (2010), pp. 1-8.

David E. Melchar and Susan m. Bosco, "Achieving High Organization Performance through Servant Leadership", The Journal of Business Inquiry Vol. 9, No.1, (2010), pp. 74-88.

Dirk van Dierendonck and Inge Nuijten, "The Servant Leadership Survey: Development and Validation of a Multidimensional Measure", Journal of Business and Psychology. Sept; 26 (3) (2011) pp. 249-267.

Dirk van Dierendonck, Sigrun Gunnarsdóttir and Kathleen A. Patterson, "Review The Functions of a Servant Leader"; Administrative Sciences, Vol.7, No.5; doi:10.3390/admsci7010005, (2017), pp. $1-32$.

Frans Mardi Hartono, Paradigma Baru Manajemen Indonesia, Menciptakan Nilai dengan Bertumpu pada Kebajikan dan Potensi Insani, Bandung: Mizan Pustaka, 2009.

Handita Sari, "Kepemimpinan yang Melayani di Sekolah Menengah Tingkat Atas Swasta Kota Salatiga", Jurnal Manajemen Pendidikan Volume: 3, No. 2, Juli-Desember (2016), pp. 265276.

IAIN Sultan Amai Gorontalo. Profil Fakultas Ilmu Tarbiyah dan Keguruan. Diakses pada tanggal 16 Pebruari 2017 dari www://iaingorontalo.ac.id 
Imam Machali dan Noor Hamid, Pengantar Manajemen Pendidikan Islam (Perencanaan, Pengorganisasian, dan Pengawasan dalam Pengelolaan Pendidikan Islam), Yogyakarta: Pustaka An Nur, 2017.

Jack Thomas McCann, Daniel Graves and Lieven Cox, "Servant Leadership, Employee Satisfaction, and Organizational Performance in Rural Community Hospitals", International Journal of Business and Management"; Vol. 9, No. 10, (2014), pp. 28-38

Jim Laub, "From Paternalism to the Servant Organization: Expanding the Organizational Leadership Assessment (OLA) Model", The International Journal Of Servant-Leadership. May Vol.1 No. 1, (2005) pp. 155-186.

Joyce W. Fields, Karen C. Thompson and Julie R. Hawkins, "Servant Leadership: Teaching the Helping Professional", Journal of Leadership Education, DOI: 1012806/V14/I4/R2, (2015), pp. 92105.

Larry C. Spears, "Character and Servant Leadership: Ten Characteristics of Effective, Caring Leaders", The Journal of Virtues \& Leadership, Vol. 1 Iss. 1, (2010), pp. 25-30.

Peter G. Northouse, Kepemimpinan Teori dan Praktik, Jakarta: Indeks, 2013.

Richard H. Savel and Cindy L. Munro, "Character and Servant Leadership: Ten Characteristics of Effective, Caring Leaders", American Journal of Critical Care, March vol. 26 no. 2, (2017), pp. 97-99

Sulisworo D, "Model Kepemimpinan Modern di Program Pascasarjana Universitas Ahmad Dahlan"Journal of Education and Learning. Vol.6 No.1 (2012), pp. 43-50.

Wekesa S. Olesia, G.S. Namusonge and Mike E. Iravo, “Achieving High Organization Performance through Servant Leadership Role of Servant Leadership on Organizational Commitment: An Exploratory Survey of State Corporations in Kenya", International Journal of Humanities and Social Science, July, Vol. 3 No. 13, (2013), pp. 85-94 